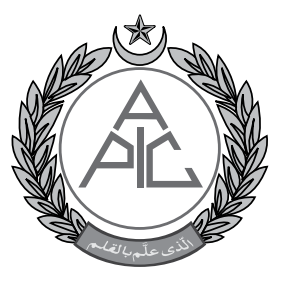

\title{
Non-cardio respiratory monitoring of mechanically ventilated critically ill patients
}

\author{
Chinmaya Kumar Panda ${ }^{1}$, MD, PDF (Crit Care Med), Habib \\ Mohammad Reazaul Karim¹, MD, DNB (Anaesth), IDCCM (Crit Care \\ Med), Subrata Kumar Singha ${ }^{1}$, MD, PDCC (Cardiac Anaesth)
}

\begin{abstract}
Critically ill patients often require multiple organ supports; respiratory support in terms of mechanical ventilation (MV) is one of the commonest. But, only providing an organ support contributes less to the complete well being of the patients. Moreover, MV itself can affect various physiological systems, metabolic response, and cause side effects. A very close temporal relationship exists between patients, monitoring and management decision too, and therefore, appropriate information from monitoring can lead to better outcomes. The present review is intended to briefly highlight the current opinions and strategies for non cardio-respiratory monitoring in such critically ill patients.
\end{abstract}

Department of Anesthesiology \& Intensive Care, All India Institute of Medical Sciences,

Raipur. India

Correspondence:

Dr Habib Mohammad

Reazaul Karim, Department

of Anesthesiology \& Intensive

Care, All India Institute of

Medical Sciences (AlIMS), Great

Eastern Rd, AlIMS Campus,

Tatibandh, Chhattisgarh 492099

(India)

Received: 9 Jul 2018

Reviewed: 1 Oct 2018

Corrected \& Accepted:

9 Oct 2018

Key words: Monitoring; Intensive Care Unit; Fluid, Temperature; Scoring; Metabolic

Abbreviations: AKI-Acute Kidney Injury; APACHE-Acute Physiology and Chronic Health Evaluation; BPS-Behavioral Pain Scale; CAM-ICU-Confusion Assessment Method for the Intensive Care Unit; CPOT-Critical Care Pain Observation Tool; EVLWI-Extra vascular lung water index; FDA-Food and Drug Administration; ISO-International Organization for Standardization; ICU-Intensive Care Unit; LOS-Length of stay; MODS-Multiple Organ Dysfunction Score; MV-Mechanical Ventilation; PaO2-Partial pressure of arterial oxygen; FiO2-Fraction of inspired oxygen; SAPS-Simplified Acute Physiologic Score; RASS-Richmond Agitation Sedation Scale; SOFA-Sequential Organ Failure Assessment; SAS-Sedation Agitation Scale; UO-Urine output

Citation: Panda CK, Karim HMR, Singha SK. Non-cardio respiratory monitoring of mechanically ventilated critically ill patients. Anaesth Pain \& Intensive Care 2018;22 Suppl 1:S150-S159

\section{INTRODUCTION}

The optimization of a critically ill mechanically ventilated patient needs early picking up the problems and appropriate and timely actions; frequent or continuous monitoring / evaluation of the patient play an important role. There is no doubt that cardio circulatory and respiratory monitoring are important in managing critically ill patients. However, other factors like hypothermia, malnutrition, glycaemia control, etc. too contributes to the morbidity and mortality of such patients. ${ }^{1,2}$ Therefore, monitoring these parameters too has a role to play for better management and outcome of mechanically ventilated critically ill patients. In the present review, monitoring will be described in different headings like nutrition and fluid balance, other physiologic parameters, disease progression monitoring, pain, sedation, delirium, etc. Neurological monitoring is not included in this review.

\section{NUTRITIONAL AND FLUID MONITORING}

\section{Nutrition:}

The European Society for Clinical Nutrition and Metabolism, Society of Critical Care Medicine and American Society for Parenteral and Enteral 
Nutrition recommends the use of indirect calorimetry to measure energy needs of intensive care patients. ${ }^{4}$, ${ }^{5,6}$ In the absence of indirect calorimetry, simplistic weight-based equation $(25-30 \mathrm{kcal} / \mathrm{kg} /$ day $)$ to be used. ${ }^{5}$ Computerized information system may help us in preventing under or over feeding in critically ill patients. ${ }^{6}$

Although enteral nutrition does not provide mortality benefit over perenteral nutrition, it was found to decreases infectious complications and intensive care unit (ICU) length of stay (LOS). ${ }^{7}$ Expert consensus suggests that the patients should be monitored daily for tolerance of enteral nutrition However, gastric residual volume should not be routinely monitored for this purpose..$^{5}$ If the patient is on parenteral nutrition, glycemia monitoring should be regular and electrolyte status should also be monitored daily. ${ }^{5,8}$

The metabolic complications with the administration of parenteral nutrition should be identified early by monitoring; clinical and laboratory-based assessment can help us doing so. If parenteral nutrition needs to be given for more than a week, trace elements and vitamin deficiencies (i.e. selenium, zinc, and copper, vitamin $\mathrm{B} 12$, folic acid, iron) are also needed to be monitored. ${ }^{9}$

Although appropriate calorie goal in critically ill patients is not precisely known and underfeeding is common in ICU patients; a permissive underfeeding with non-protein calorie has been found to be equivalent in terms of mortality, ICU LOS, duration of mechanical ventilation etc, as compared to standard enteral feeding practice. ${ }^{10,11}$ However, how much underfeeding, which patients; especially nutrition high risk patient will benefit or not is still not clear and a question of direct research. A modified NUTRIC score has been proposed, validated and can be used as risk screening tool for detecting high risk group which may benefit from standard feeding. ${ }^{12,13}$

\section{Fluid balance:}

Increased fluid administration and positive balance were associated with greater risk of AKI after major surgery. ${ }^{14}$ As compared with even fluid balance, exposure to positive or negative fluid balance has been shown to be associated with higher 1-year mortality in critically ill patients. ${ }^{15}$ Positive fluid balance has shown to have a trend towards prolonged mechanical ventilation. ${ }^{16}$

It has been found that a negative fluid balance of $\leq$ $500 \mathrm{ml}$ achieved in any of the first 3 days of septic shock is a good independent predictor of survival in patients with septic shock. ${ }^{17}$ The higher cumulative fluid balance at third day after ICU admission was independently associated with an increase mortality hazard in sepsis patients, but not the higher fluid balance in the first 24 hours. ${ }^{18}$

Usually fluid balance is monitored by using input / output charting. However, this method is known for inaccuracy. A quality improvement program however showed that education and rationalization of monitoring can improve completion and accuracy of monitoring. ${ }^{19}$

As a result of fluid retention in the body, hydrostatic pressure increases which in turn can lead to accumulation of water in the interstitial and alveolar spaces. This amount of water is also known as extra vascular lung water, which has been shown to be a good predictor of mortality in critically ill patients. ${ }^{20}$ Transpulmonary thermodilution based technique to measure extra vascular lung water index (EVLWI) and pulmonary vasculature permeability index allow clinicians to monitor the volume of lung edema at the bedside. ${ }^{21}$ Although negative fluid balance protocol based on EVLWI has shown to rapidly increase oxygenation, in hypoxemic patients, decrease LOS in ICU and MV duration in patients with ARDS; the benefit in terms of survival of patient management based on this monitoring still need to be proven. ${ }^{22}$, ${ }^{23}$ However, Monitoring of fluid balance is strongly recommended targeting "near zero". Daily check for edema and fluid retention should be done. ${ }^{9}$

\section{Glycemic monitoring:}

Since the publication of Van Den Berghe study in 2001 showing more than $40 \%$ (4.6\% versus $8 \%$ ) reduction in mortality with intensive insulin therapy in intensive care patients receiving mechanical ventilation, the glycemic control and monitoring has remained a hot debatable topic in critical care medicine. ${ }^{24}$ The NICE-SUGAR investigators showed that intensive insulin therapy to target tight control blood sugar as compared to conventional management increased mortality; frequent hypoglycemia in tight control group was probably one of the cause. ${ }^{25}$ Another multi centre study including pediatric patients found no mortality and ventilator-free survival benefit in the tight control group. ${ }^{26}$ On the other hand, the SPRINT study showed that tight glucose control resolved organ failure faster with decreasing mortality. ${ }^{27}$ Therefore it is very much clear that glucose is not an innocent molecule and both hypoglycemia and hyperglycemia in critically ill patients are deleterious. ${ }^{28}$ Hyperglycemia in critically ill patients even in patients without diabetes is common. Insulin based treatment regimen has shown to reduce morbidity and mortality in such patients and is recommended. ${ }^{29,30}$ Even the high 
variability in glucose level has been shown to increase ICU mortality. ${ }^{31}$ To detect both the condition we have to estimate the blood sugar level and at present blood sugar monitoring is regarded as a standard of care in critical care. Blood sugar measurement even depends on the sample used (i.e. capillary blood versus arterial blood) and glucose monitoring with capillary blood is reliable only in a selected group of critically ill patients. ${ }^{32}$ The monitoring should have a good accuracy too as management depends very much on the values. Therefore, the question surrounds the clinical practice is whether we should use continuous glucose monitoring in such patients? However, most of the technology and monitoring devices for continuous glucose monitoring is still not having precise accuracy required as per mean absolute relative difference (MARD) point accuracy standard adopted. ${ }^{33,34} \mathrm{~A}$ recent study found the performance of the OptiScanner ${ }^{\circledR}$ as adequate for use in ICU patients based on the MARD. ${ }^{35}$ However, it did not meet the requirements as per consensus recommendation of ISO 151972013 and FDA. ${ }^{36} \mathrm{~A}$ recent analysis using the StatStrip Glucose (Nova Biomedical, Waltham, MA) found that the accuracy was acceptable for use in critically ill patient settings when compared standard laboratory method. ${ }^{37}$ This finding again let the fight between intermittent glucose measurements versus continuous glucose measurement continued.

\section{OTHER PHYSIOLOGICAL MONITORING}

\section{Temperature}

Both hypothermia and hyperthermia can adversely affect the critically ill patients and maintenance of normothermia is critical in such patients. ${ }^{38}$ Therefore temperature monitoring is routine or should be done in all patients. In unstable patients or in patients where targeted temperature moitoring is required, continous invasive temperature monitoring using bladder catheter or esophageal probe is advised. Otherwise temperature monitoring in the axilla is reasonable. ${ }^{39}$

\section{Urine output}

Although urine output (UO) can change with transitory volume status and different drugs used in critically ill patient, it has been regarded as a relevant marker of kidney function and an independent marker of serum creatinine. Oliguria of $>12$ hours and Oliguria of more than 3 episodes are shown to be associated with increased mortality. ${ }^{40}$ On the other hand hourly monitoring of UO and no gaps of $>3$ hours for the first 48 hours after ICU admission, was associated with improved AKI detection, reduced 30-day mortality in patients experiencing AKI, as well as less fluid overload for all patients. ${ }^{41} \mathrm{UO}$ is also a criterion for diagnosing and staging AKI. ${ }^{42}$ As UO monitoring can help clinicians in patient triage, prognostication and evaluating response to treatment, assessment of UO has been advocated as clinical quality measure. ${ }^{43}$

\section{OUTCOME PREDICTION AND MONITORING IN ICU}

In the era of evidence-based medicine, quantifying the disease severity, prognostication and therapeutic intervention are all based on several scoring systems. Diversities in intensive care practice, more likelihood of death and the huge financial burden on the family led to the development of the various clinical scoring systems. Scoring systems are broadly divided into two types; organ specific (e.g. Glasgow coma scale) and generic (e.g. Acute Physiology and Chronic Health Evaluation score). In order to improvise on the practice, establishment of an objective and a reproducible scoring system is essential. The outcome prediction scores to provide an indication of risk of death in the ICU were developed originally more than 25 years ago. ${ }^{44}$ Recently, the predictive scoring systems were updated in 2007 to continue accuracy in determining mortality in ICUs.

\section{Acute Physiology and Chronic Health Evaluation (APACHE)}

This was the first of its kind predictive scoring system originally developed in 1981 in the United States by Knaus WA, et al. to predict severity of illness. ${ }^{45}$ Age, origin and acute diagnosis of the patient were subsequently added to APACHE II, APACHE III and APACHE IV, which enhanced the ability of the prediction of mortality. This system takes input of a large number of clinical variables from which score are derived. Selection of variables and its weight are done through multiple logistic regressions which predict the outcome. APACHE II was the most widely used version because of its simplicity. This was validated in 5030 ICU patients. It comprises of three components; an acute physiology score (APS), a chronic health based on defined pre-morbid states and a score based on the patient's age. APACHE IV, the latest version (2006), uses 129 variables taking the worst value in the first 24 hours after ICU admission. ${ }^{46}$ This version is superior to its previous ones in predicting the mortality accurately [46]. Another study found that APACHE IV predicted the ICU length of stay more accurately than APACHE II, APACHE III, Simplified Acute Physiologic Score (SAPS) 3, and the Mortality Prediction Model (MPM)-III. ${ }^{47}$ It has got superior 
discrimination capability than the contemporary scoring systems supported by external validation studies ${ }^{48}$ But this tool requires a periodic updating of variables in order to obtain an impressive calibration. In addition, data entry in this is burdensome which requires an electronic record system. The validity of this scoring is only tested in the United States which may not be true for other countries.

\section{Simplified Acute Physiologic Score (SAPS)}

In 1984, Le Gall JR et al. developed a predictive scoring system, Simplified Acute Physiologic Score (SAPS) by taking 14 acute physiological variables into account in French ICUs. Later on, this scoring was applied in various European and American ICUs and two more versions have been developed in 1993 and 2005. The variables were mostly dichotomous (e.g. present or absent) and others are continuous (e.g. age group). SAPS 3 was the latest one in the segment, data derived from 303 ICUs, with good discrimination, but poorer calibration as compared to APACHE IV and MPM-III..$^{49,50,51}$ Data extraction is comparatively easier in this than APACHE IV. In addition, this can be generalized to a global platform as the data were derived were from various countries. This can be used as a tool in studies comparing resource use between ICUs. Unlike APACHE, this cannot predict the ICU length of stay. ${ }^{52}$

\section{Mortality Prediction Model (MPM0)}

The first mortality prediction model (MPM0) developed in 1985 by taking data from one ICU. A severity score is calculated from variables, as assessed at the time of ICU admission (hence the term "0"). MPM0-III developed in 2004, uses 16 variables, including 3 physiological parameters, obtained within 1 hour of ICU admission; ${ }^{53}$ therefore, it depends on the patients' condition largely before ICU admission. All except for age, data were dichotomous in nature. The data were entered into a logistic regression model which provides the predicted mortality at the time of discharge. There is some evidence that MPM -III provides more accurate prediction of ICU mortality than MPM -II..$^{53}$ The data extraction was easier in this system as they do not use laboratory data, but rather clinical and physiological data. Like SAPS 3, this also does not predict the length of stay in ICU. This is also susceptible to poor performance when subjected to increased case mix over time.

\section{Organ dysfunction scores}

Organ dysfunction scores are primarily designed to describe the extent of organ dysfunction. Severity of dysfunction changes with time and varies widely among the individuals as well as within an individual.
Many scoring systems were derived, out of which 3 are most widely used in the ICUs; Multiple Organ Dysfunction Score (MODS), the Sequential Organ Failure Assessment (SOFA), and the Logistic Organ Dysfunction Score (LODS). Pettilä V et al. reported that the comparable discriminating power of APACHE III, LODS, MODS, SOFA were rather good, with each other, and comparable within prediction of hospital mortality. ${ }^{54} \mathrm{~A}$ recent study in patients with brain injury found that the SOFA score was having superior discriminative ability for unfavourable neurologic outcome and hospital mortality as compared to MODS. ${ }^{55}$ However, we have to understand that the scoring system cannot replace the ICU physician here too. Finding of studies suggest that the discrimination between survivors and nonsurvivors in the first $24 \mathrm{hrs}$ of ICU admission is more accurately done by the ICU physicians than by the scoring systems. However, the study found the overall accuracy as moderate. This finding implies limited usefulness of outcome prediction by the score in the first $24 \mathrm{hrs}$ for clinical decision making. ${ }^{56}$

The SOFA score was developed in a consensus conference in 1994. Six organ systems (i.e. cardiovascular, respiratory, central nervous, renal, hepatic, coagulation) are taken into consideration and the function of each scored from 0 (normal) to 4 (most abnormal), giving a possible score of 0 to 24 (table-1). The scores are calculated 24 hours after admission to the ICU and every 48 hours thereafter. Unlike MODS where the first value of the day was recorded, in SOFA the worst value of the day was recorded. In addition, scores that increase by about 30 percent are associated with a mortality of at least 50 percent. ${ }^{57}$ Cabre $\mathrm{L}$ et al. reported in a prospective observational study conducted in 79 ICUs that in patients' aged more than 60 years with SOFA score of more than 9 for five consecutive days were unlikely to survive. ${ }^{58}$ The predictive validity of this score for in-hospital mortality was superior to systemic inflammation response criteria (SIRS) as well. SOFA and Modified SOFA scoring systems has been shown to be better than APACHE II system in predicting mortality in ICU surgical patients. The study also found that serial measurements of SOFA and Modified SOFA score improve their predictive accuracy significantly. ${ }^{59}$ The SOFA score have been endorsed as a tool by the European Society of Intensive Care Medicine and the Society of Critical Care Medicine to facilitate the identification of patients at risk of dying from sepsis. ${ }^{60,61,62}$ The limitation of this score is that, it has taken treatment with vasopressors into account which varies significantly among the institutions, patients and over time. 
[ ${ }^{a}$ Adrenergic agents administered for at least $1 \mathrm{~h}$ (doses in $\mu \mathrm{g} / \mathrm{kg}$-min), SOFA- Sequential Organ Failure Assessment, GCS - Glasgow Coma Scale , $\mathrm{PaO}_{2}$ - arterial partial pressure of oxygen. $\mathrm{FiO}_{2}-$ fraction of inspired of oxygen]

\section{PAIN, DELIRIUM, SEDATION AND AGITATION MONITORING}

The most common and distressing experience for a patient in an intensive care setting is a pain ${ }^{63}$ which further leads to agitation and delirium if it is not controlled timely and effectively. Mechanical ventilation, invasive procedures and the ICU environment itself are the culprits for the 'ICU triad' of pain, agitation and delirium. Thus, the assessment of pain and adequate analgesia are an essential component of ICU care. The reference standard for assessment of pain is mostly self-reported by the patients in ICU, but the patients are mostly less interactive which require alternative scoring methods such as behavioral pain scale (BPS), CriticalCare Pain Observation Tool (CPOT), physiological parameters etc.

\section{Pain assessment in a communicative patient:}

Table 1: The SOFA score

\begin{tabular}{|c|c|c|c|c|}
\hline Parameters & 1 & 2 & 3 & 4 \\
\hline $\begin{array}{l}\text { Respiration } \\
\mathrm{PaO2} \text { / Fi02 }\end{array}$ & $<400$ & $<300$ & $\begin{array}{c}<200 \\
\text { with respiratory } \\
\text { support }\end{array}$ & $\begin{array}{l}\quad<100 \\
\text { with respiratory } \\
\text { support }\end{array}$ \\
\hline $\begin{array}{l}\text { Coagulation } \\
\text { Platelets x 103/ } \\
\text { mm } 3\end{array}$ & $<150$ & $<100$ & $<50$ & $<20$ \\
\hline $\begin{array}{l}\text { Hepatic } \\
\text { Bilirubin mg/dl } \\
\text { (micro mol/1) }\end{array}$ & $\begin{array}{l}1.2-1.9 \\
(20-32)\end{array}$ & $\begin{array}{c}2.0-5.9 \\
(33-101)\end{array}$ & $\begin{array}{c}6.0-11.9 \\
(102-204)\end{array}$ & $\begin{array}{l}>12.0 \\
(>204)\end{array}$ \\
\hline $\begin{array}{l}\text { Cardiovascular } \\
\text { Blood Pressure }\end{array}$ & $\begin{array}{c}\mathrm{MAP}<70 \\
\mathrm{mmHg}\end{array}$ & $\begin{array}{c}\text { Dopamine } \leq 5 \text { or } \\
\text { dobutamine (any } \\
\text { dose)a }\end{array}$ & $\begin{array}{c}\text { Dopamine }>5 \text { or } \\
\text { epinephrine } \leq 0.1 \\
\text { or norepinephrine } \\
\quad \leq 0.1\end{array}$ & $\begin{array}{c}\text { Dopamine }>15 \\
\text { or epinephrine }> \\
0.1 \text { or norepi- } \\
\text { nephrine }>0.1\end{array}$ \\
\hline $\begin{array}{l}\text { Central nervous } \\
\text { system } \\
\text { GCS }\end{array}$ & $13-14$ & $10-12$ & $6-9$ & $<6$ \\
\hline $\begin{array}{l}\text { Renal } \\
\text { Creatinine, } \mathrm{mg} / \mathrm{dl} \\
\text { (micro mol/1) or } \\
\text { urine output }\end{array}$ & $\begin{array}{c}1.2-1.9 \\
(110-170)\end{array}$ & $\begin{array}{c}2.0-3.4 \\
(171-299)\end{array}$ & $\begin{array}{c}3.5-4.9 \\
(300-440) \text { or }< \\
500 \mathrm{ml} / \text { day }\end{array}$ & $\begin{array}{c}>5.0 \\
(>440) \text { Or }< \\
200 \mathrm{ml} / \text { day }\end{array}$ \\
\hline
\end{tabular}

Table 2: Behavioral Pain Scale ${ }^{21}$

\begin{tabular}{l|l|c}
\multirow{2}{*}{ Item } & \multicolumn{1}{c}{ Description } & Scores \\
\hline & Relaxed & 1 \\
\cline { 2 - 3 } & Partially tightened (for example, brow lowering) & 2 \\
\cline { 2 - 3 } & Fully tightened (for example, eyelid closing) & 3 \\
\cline { 2 - 3 } & Grimacing & 4 \\
\hline \multirow{2}{*}{ Upper limb } & No movement & 1 \\
\cline { 2 - 3 } & Partially bent & 2 \\
\cline { 2 - 3 } & Fully bent with finger flexion & 3 \\
\cline { 2 - 3 } & Permanently retracted & 4 \\
\hline ventilation & Tolerating movement & 2 \\
\cline { 2 - 3 } & Coughing but tolerating ventilation for most of the time & 3 \\
\cline { 2 - 3 } & Fighting ventilator & 4 \\
\cline { 2 - 3 } & Unable to control ventilation & 1 \\
\hline
\end{tabular}

The numeric rating scale is a verbal rating of pain by the patient itself starting from 0 to 10,10 being the worst pain experienced. An enlarged horizontal NRS was the most valid pain intensity rating scale tested among ICU patients. ${ }^{64}$ Visual analog scale (VAS) is a similar pain scoring system, having scores 0 to 100,100 being the worst pain. These scores are used for the non-ventilated and mildly sedated and co-operative patients.

2. Pain assessment in a noncommunicative patient:

Self-reporting is mostly a difficult task in ICU as most patients are mechanically ventilated or sedated. The pain scoring systems in these patients is inspired from pediatrics pain scales like COMFORT and FLACC (Face, Legs, Activity, Cry, Consolability Observational Tool) scale. ${ }^{65}$ The behavior pain scale (BPS) is specifically designed for the non-communicative adult patients in ICU which is based on the sum score of three items: facial expression, movements of the upper limbs and compliance with mechanical ventilation. Each pain indicator is scored from 1 (no response) to 4 (full response), with a maximum score of 12 (Table 2).

The BPS is supported by a large 
body of research and has been recommended for use in critical care settings for monitoring pain in medical, postoperative, or trauma (except for brain injury) adult ICU patients who are unable to self-report and in whom motor function is intact and behaviors are observable. ${ }^{63}$ However, the responsiveness (increase in score in response to noxious stimuli) decreases with increase in sedation which limits the score. ${ }^{66}$ Four behavioral categories are taken into account for the CPOT, which are facial expression, body movements, muscle tension, and vocalization (for extubated patients) or compliance with mechanical ventilators (for ventilated patients); each of which is scored on a 0 to 2 scale of various verbal descriptors, with a possible total score ranging from 0 to 8 (Table 3 ). Because of its simplicity nurses found it easier to use. ${ }^{67}$ Severgnini P et al. have shown in their study that the combination of both BPS and Critical Care Pain Observation Tool (CPOT) have shown improved accuracy to detect pain compared to one scales. ${ }^{68}$

\section{Sedation and agitation monitoring tools:}

Sedation monitoring often goes unmonitored in ICU which lead to various adverse effects such as increase in the ICU length of stay, ventilator associated pneumonia etc. Further, undersedation is also harmful for the patient creating a bad experience in the ICU stay. So, adjustment of dosage of sedatives in an ICU and its interruption requires monitoring of level of sedation. Evidence suggests improvement in patient outcome if sedation is monitored routinely in ICU. ${ }^{69}$ Many scoring systems have
Table 3: Critical Care Pain Observational Tool

\begin{tabular}{|c|c|c|}
\hline Indicators & Description & Scores \\
\hline \multirow[t]{3}{*}{ Facial expression } & No muscular tension observed & Relaxed, neutral: 0 \\
\hline & $\begin{array}{l}\text { Presence of frowning, brow lowering, orbit tightening, } \\
\text { and levator contraction }\end{array}$ & Tense: 1 \\
\hline & $\begin{array}{l}\text { All of the above facial movements plus eyelid tightly } \\
\text { closed }\end{array}$ & Grimacing: 2 \\
\hline \multirow[t]{3}{*}{ Body movements } & $\begin{array}{l}\text { Does not move at all (does not necessarily mean } \\
\text { absence of pain) }\end{array}$ & $\begin{array}{l}\text { Absence of } \\
\text { movements: } 0\end{array}$ \\
\hline & $\begin{array}{l}\text { Slow, cautious movements, touching or rubbing the pain } \\
\text { site, seeking attention through movements }\end{array}$ & Protection: 1 \\
\hline & $\begin{array}{l}\text { Pulling tube, attempting to sit up, moving limbs/ } \\
\text { thrashing, not following commands, striking at staff, } \\
\text { trying to climb out of bed }\end{array}$ & Restlessness: 2 \\
\hline \multirow[t]{3}{*}{ Muscle tension } & No resistance to passive movements & Relaxed: 0 \\
\hline & Resistance to passive movements & Tense, rigid: 1 \\
\hline & $\begin{array}{l}\text { Strong resistance to passive movements, inability to } \\
\text { complete them }\end{array}$ & Very tense or rigid: 2 \\
\hline \multirow[t]{3}{*}{$\begin{array}{l}\text { Compliance with } \\
\text { the ventilator }\end{array}$} & Alarms not activated, easy ventilation & $\begin{array}{c}\text { Tolerating ventilator } \\
\text { or } \\
\text { ventilator movement: } \\
0\end{array}$ \\
\hline & Alarms stop spontaneously & $\begin{array}{l}\text { Coughing but } \\
\text { tolerating : } 1\end{array}$ \\
\hline & $\begin{array}{l}\text { Asynchrony: blocking ventilation, alarms frequently } \\
\text { activated }\end{array}$ & Fighting ventilator: 2 \\
\hline \multirow{3}{*}{$\begin{array}{l}\text { OR } \\
\text { Vocalization } \\
\text { (extubated } \\
\text { patients) }\end{array}$} & Talking in normal tone or no sound & $\begin{array}{l}\text { Talking in normal } \\
\text { tone or no sound: } 0\end{array}$ \\
\hline & Sighing, moaning & Sighing, moaning: 1 \\
\hline & Crying out, sobbing & $\begin{array}{l}\text { Crying out, sobbing: } \\
2\end{array}$ \\
\hline
\end{tabular}

Table 4: Riker Sedation-Agitation Scale (SAS)

\begin{tabular}{l|l|c}
\hline \multicolumn{1}{l}{ Terms } & \multicolumn{1}{c}{ Description } \\
$\begin{array}{l}\text { Dangerous } \\
\text { agitation }\end{array}$ & $\begin{array}{l}\text { Pulling at endotracheal tube, trying to remove catheters, } \\
\text { climbing over bed rail, striking at staff, thrashing from } \\
\text { side to side }\end{array}$ & 7 \\
\hline Very agitated & $\begin{array}{l}\text { Requiring restraint and frequent verbal reminding of } \\
\text { limits, biting endotracheal tube }\end{array}$ & 6 \\
\hline Agitated & $\begin{array}{l}\text { Anxious or physically agitated, calming at verbal } \\
\text { instruction }\end{array}$ & 5 \\
\hline $\begin{array}{l}\text { Calm and } \\
\text { cooperative }\end{array}$ & $\begin{array}{l}\text { Calm, easily arousable, follows commands } \\
\text { Sedated }\end{array}$ & $\begin{array}{l}\text { Difficult to arouse but awakens to verbal stimuli or } \\
\text { gentle shaking; follows simple commands but drifts off } \\
\text { again }\end{array}$ \\
\hline $\begin{array}{l}\text { Very sedated } \\
\text { aroused }\end{array}$ & $\begin{array}{l}\text { Arouses to physical stimuli but does not communicate } \\
\text { or follow commands, may move spontaneously }\end{array}$ & 4 \\
\hline
\end{tabular}


monitoring of mechanically ventilated patients

Table 5: Richmond Agitation-Sedation Scale (RASS)

\begin{tabular}{l|l|c}
\multicolumn{1}{l}{ Score } & \multicolumn{1}{c}{ Description } & Scores \\
\hline Combative & Overtly combative, violent, immediate danger to staff & 4 \\
\hline Very agitated & Pulls or removes tubes or catheters; aggressive & 3 \\
\hline Agitated & Frequent non-purposeful movement, fights ventilator & 2 \\
\hline Restless & Anxious but movements not aggressive or vigorous & 1 \\
\hline Alert and calm & Alert and calm & 0 \\
\hline
\end{tabular}

been suggested, of which Riker Sedation Agitation Scale (SAS) and the Richmond Agitation Sedation Scale (RASS) are the most common but neither is superior when compared. ${ }^{70}$ SAS ranges from 1 (not arousable) to 7 (dangerous agitation), 4 being the calm and cooperative patients (Table 4). RASS ranges from -5 (not arousable) to +4 (combative), 0 being the alert and calm patient (Table 5).

\section{Delirium:}

Nearly one third of the ICU patients develop delirium and these patients are at increased risk of mortality. Delirium also leads to the longer stays in hospital, and is even associated with cognitive impairment after discharge..$^{71}$ Routine monitoring of delirium has been shown to improve outcome in surgical ICU patients. ${ }^{72}$ On the other hand, monitoring delirium using the Confusion Assessment Method for the Intensive Care Unit (CAM-ICU) failed to show benefit in general ICU patients. ${ }^{73}$ However, considering the significant impact on the patient, it appears to good practice to monitor delirium at least once in a day. A clinical practice guideline recommends that the delirium should be regularly assessed in all adult ICU patients by using either the CAM-ICU or the Intensive Care Delirium Screening Checklist (ICDSC). ${ }^{63}$

\section{CONCLUSION}

Non cardio circulatory and respiratory monitoring are equally important in critically ill ventilated patients. Although, there are no clear cut strong recommendations, it will be good clinical practice to monitor temperature should be monitored continuously like vitals monitoring; urine output should be monitored every hour. Pain, glycemic control, and sedation and agitation monitoring should be frequent. Cumulative fluid balance, presence of delirium and nutritional requirement and need of supplementation should be also assessed daily. Progression of disease and severity of illness should be assessed serially.

Conflict of interest: The authors declares no conflict of interest. The authors declares no competing interest

Authors' contribution: All authors took part in data collection, literature review and manuscript preparation

\section{REFERENCES}

1. Lew CCH, Wong GJY, Cheung KP, Chua AP, Chong MFF, Miller M. Association between Malnutrition and 28-Day Mortality and Intensive Care Length-of-Stay in the Critically ill: A Prospective Cohort Study. Nutrients 2017;10(1).pii:E10. [PubMed] [Full text] [Crossref]

2. Laupland KB, Zahar JR, Adrie C, Schwebel C, Goldgran-Toledano D, Azoulay $\mathrm{E}$, et al. Determinants of temperature abnormalities and influence on outcome of critical illness. Crit Care Med 2012;40:145-51. [PubMed] [Full Text] [Crossref]

3. Kreymann KG, Berger MM, Deutz $\mathrm{NE}$, Hiesmayr M, Jolliet P, Kazandjiev G, et al. ; ESPEN (European Society for Parenteral and Enteral Nutrition). ESPEN Guidelines on Enteral Nutrition: Intensive care. Clin Nutr r . . 7;25:210 -
23. [PubMed] [Full Text] [Crossref]

4. Singer $P$, Berger MM, Van den Berghe G, Biolo G, Calder P, Forbes A, et al.; ESPEN. (European Society for Parenteral and Enteral Nutrition) ESPEN Guidelines on Parenteral Nutrition: intensive care. Clin Nutr 2009;28:387400. [PubMed] [Full Text] [Crossref]

5. McClave SA, Taylor BE, Martindale RG, Warren MM, Johnson DR, Braunschweig $C$, et al. Guidelines for the Provision and Assessment of Nutrition Support Therapy in the Adult Critically III Patient: Society of Critical Care Medicine (SCCM) and American Society for Parenteral and Enteral Nutrition (A.S.P.E.N.). J Parenter Enteral Nutr 2016;40:159-211. [PubMed] [Full Text] [Crossref]

6. Berger MM, Revelly JP, Wasserfallen JB, Schmid A, Bouvry S, Cayeux
$\mathrm{MC}$, et al. Impact of a computerized information system on quality of nutritional support in the ICU. Nutrition 2006;22:221-9. [PubMed] [Full Text pdf] [Crossref]

7. Elke G, van Zanten $A R H$, Lemieux M, Margot Lemieux, Michele McCall, Khursheed N, et al. Enteral versus parenteral nutrition in critically ill patients: an updated systematic review and meta-analysis of randomized controlled trials. Crit Care 2016;20:117. [PubMed] [Full Text] [Crossref]

8. Macdonald, K, Page, K, Brown, $L$ Parenteral nutrition in critical care. Contin Educ Anaesth Crit Care Pain 2013;13:1-5. [ [Eull Text] [Crossref]

9. Cotogni P. Management of parenteral nutrition in critically ill patients. World 
J Crit Care Med 2017;6:13-20. [PubMed] [Full Text pdf] [Crossref]

10. Arabi YM, Aldawood AS, Al-Dorzi HM, Tamim HM, Haddad SH, Jones $\mathrm{G}$, et al ; PermiT trial group. Permissive Underfeeding or Standard Enteral Feeding in High- and Low-NutritionalRisk Critically III Adults. Post Hoc Analysis of the PermiT Trial. Am J Respir Crit Care Med 2017;195:65262. [PubMed] [Full Text] [Crossref]

11. Stuani Franzosi 0, Delfino von Frankenberg A, Loss SH, Silva Leite Nunes $D$, Rios Vieira SR. Underfeeding versus full enteral feeding in critically ill patients with acute respiratory failure: a systematic review with meta-analysis of randomized controlled trials. Nutr Hosp r . I V;34:19-29. [PubMed] [Full Text] [Crossref]

12. Mendes R, Policarpo S, Fortuna P, Alves M, Virella D, Heyland DK; Portuguese NUTRIC Study Group. Nutritional risk assessment and cultural validation of the modified NUTRIC score in critically ill patients-A multicenter prospective cohort study. J Crit Care 2017;37:45-9. [PubMed] [Full Text] [Crossref]

13. De Vries MC, Koekkoek W (Kristine), Opdam $\mathrm{MH}$, van Blokland $\mathrm{D}$, van Zanten AR. Nutritional assessment of critically ill patients: validation of the modified NUTRIC score. Eur J Clin Nutr 2018;72:428-35. [PubMed] [Full Text] [Crossref]

14. Weinberg L, Li M, Churilov L, Armellini A, Gibney $M$, Hewitt $T$, et al. Associations of fluid amount, type, and balance and acute kidney injury in patients undergoing major surgery. Anaesth Intensive Care 2018;46:79-0. [PubMed] [Full Text]

15. Balakumar $\mathrm{V}$, Murugan $\mathrm{R}$, Sileanu FE, Palevsky P, Clermont G, Kellum JA.Both Positive and Negative Fluid Balance May Be Associated With Reduced Long-Term Survival in the Critically III. Crit Care Med 2017;45(8):e749-e757. [PubMed] [Full Text] [Crossref]

16. Vidal S, Pérez A, Eulmesekian P. Fluid balance and length of mechanical ventilation in children admitted to a single Pediatric Intensive Care Unit. Arch Argent Pediatr 2016;114:313-8. [PubMed] [Full Text pdf] [Crossref]

17. Alsous $F$, Khamiees $M$, DeGirolamo A, Amoateng-Adjepong $Y$, Manthous CA. Negative fluid balance predicts survival in patients with septic shock: a retrospective pilot study. Chest 2000;117:1749-54. [PubMed] [ㅍull Text] [Crossref]

18. Sakr $Y$, Rubatto Birri PN, Kotfis K, Nanchal R, Shah B, Kluge S,et al. ; Intensive Care Over Nations Investigators. Higher Fluid Balance Increases the Risk of Death From Sepsis: Results From a Large International Audit. Crit Care Med 2017;45:386-394. [PubMed] [Full Text] [Crossref]

19. VincentM, Mahendiran T. Improvement of fluid balance monitoring through education and rationalisation. BMJ Qual Improv Rep 2015;4(1):u209885. w4087. [PubMed] [Full Text] [Crossref]

20. Zhang Z, Lu B, Ni H. Prognostic value of extravascular lung water index in critically ill patients: a systematic review of the literature. J Crit Care 2012;27:420.e1-8. [PubMed] [ㄷll Text] [Crossref]

21. Jozwiak M, Teboul J-L, Monnet X. Extravascular lung water in critical care: recent advances and clinical applications. Ann Intensive Care 2015;5:38. [PubMed] [Full Text] [Crossref]

22. Díaz-Rubia L, Ramos-Sáez S, Vázquez-Guillamet R, Guerrero-López F, Pino-Sánchez F, García-Delgado M, et al. Efficacy of an extravascular lung water-driven negative fluid balance protocol. Med Intensiva 2015;39:34551. [PubMed] [Full Text] [Crossref]

23. $\mathrm{Hu}$ W, Lin $\mathrm{C}-\mathrm{W}$, Liu B-W, Hu W-H, Zhu $Y$. Extravascular lung water and pulmonary arterial wedge pressure for fluid management in patients with acute respiratory distress syndrome. Multidiscip Respir Med 2014;9:3. [PubMed] [Full Text pdf] [Crossref]

24. van den Berghe $G$, Wouters P, Weekers $F$, Verwaest C, Bruyninckx F, Schetz $M$, et al. Intensive insulin therapy in critically ill patients. N Engl J Med 2001;345:1359-67. [PubMed] [Full Text] [Crossref]

25. Finfer S, Chittock DR, Su SY, Blair D, Foster D, Dhingra V, et al; NICESUGAR Study Investigators. Intensive versus conventional glucose control in critically ill patients. $\mathrm{N}$ Engl $\mathrm{J}$ Med 2009;360:1283-97. [PubMed] [ㅍull Text] [Crossref]

26. Macrae D, Grieve R, Allen E, Sadique Z, Morris K, Pappachan J, et al.; CHiP Investigators. A randomized trial of hyperglycemic control in pe- diatric intensive care. $\mathrm{N}$ Engl $\mathrm{J}$ Med 2014;370:107-18. [PubMed] [․ull Text] [Crossref]

27. Chase JG, Pretty CG, Pfeifer L, et al. Organ failure and tight glycemic control in the SPRINT study. Crit Care 2010;14:R154. [PubMed] [Full Text] [Crossref]

28. Pérez-Calatayud ÁA, Guillén-Vidaña A, Fraire-Félix IS, Anica-Malagón ED, Briones Garduño JC, Carrillo-Esper R. Metabolic control in the critically ill patient an update: hyperglycemia, glucose variability hypoglycemia and relative hypoglycemia. Cir Cir 2017;85:93-100. [PubMed] [Full Text] [Crossref]

29. Langley J, Adams G.Insulin-based regimens decrease mortality rates in critically ill patients: a systematic review. Diabetes Metab Res Rev 2007;23:184-92. [PubMed] [Full Text] [Crossref]

30. Jacobi J, Bircher N, Krinsley J, Agus M, Braithwaite SS, Deutschman C, et al. Guidelines for the use of an insulin infusion for the management of hyperglycemia in critically ill patients. Crit Care Med 2012;40:3251-76. [PubMed] [Full Text] [Crossref]

31. Egi M, Bellomo R, Stachowski $E$, French CJ, Hart G. Variability of blood glucose concentration and shortterm mortality in critically ill patients. Anesthesiology 2006;105:244-52. [PubMed] [Full Text]

32. Li X, Ma Y, Chen T, Tang J, Ma X. Bedside Blood Glucose Monitoring in Critically III Patients: Comparison Between Arterial and Capillary Glucose. Am J Med Sci 2017;354:458-461. [PubMed] [Full Text] [ㅁossref]

33. Krinsley JS, Chase JG, Gunst J, Johan Martensson J, Schultz MJ, Taccone FS, et al. Continuous glucose monitoring in the ICU: clinical considerations and consensus. Crit Care 2017;21:197. [PubMed] [Full Text pdf] [Crossref]

34. Wernerman J, Desaive T, Finfer $\mathrm{S}$, Foubert L, Furnary A, Holzinger U, et al. Continuous glucose control in the ICU: report of a 2013 round table meeting. Crit Care 2014;18:226. [PubMed] [Full Text] [ㄷossref]

35. Righy Shinotsuka C, Brasseur A, Fagnoul D, So T, Vincent JL, Preiser JC. Manual versus Automated moNitoring Accuracy of GlucosE II (MANAGE II) Crit Care. 2016;20:380. [PubMed] 
[Full Text] [Crossref]

36. Finfer S, Wernerman J, Preiser JC, Cass T, Desaive T, Hovorka R, et al. Clinical review: Consensus recommendations on measurement of blood glucose and reporting glycemic control in critically ill adults. Crit Care 2013;17:229. [PubMed] [Full Text] [Crossref]

37. DuBois JA, Slingerland RJ, Fokkert M, Roman A, Tran NK, Clarke W, et al. Bedside Glucose Monitoring-ls it Safe? A New, Regulatory-Compliant Risk Assessment Evaluation Protocol in Critically III Patient Care Settings. Crit Care Med 2017;45:567-574. [PubMed] [Full Text] [Crossref]

38. Laupland KB, Zahar JR, Adrie C, Schwebel C, Goldgran-Toledano D, Azoulay E, et al. Determinants of temperature abnormalities and influence on outcome of critical illness. Crit Care Med 2012;40:145-51. [PubMed] [Full Text] [Crossref]

39. Temperature Measurement for Critically ill Adults a Clinical Practice Guideline; 2014. p. 1-30. [Last accessed on 2017 Nov 20] Available from: https:// www.aci.health.nsw.gov.au/.

40. Macedo E, Malhotra R, Bouchard J, Wynn SK, Mehta RL. Oliguria is an early predictor of higher mortality in critically ill patients. Kidney Int 2011;80:760-7. [PubMed] [Full Text] [Crossref]

41. Jin K, Murugan R, Sileanu FE, Foldes E, Priyanka P, Clermont G, et al. Intensive Monitoring of Urine Output Is Associated With Increased Detection of Acute Kidney Injury and Improved Outcomes. Chest 2017;152:972-9. [PubMed] [Full Text] [ [

42. Kidney Disease: Improving Global Outcomes (KDIGO) Acute Kidney Injury Work Group. KDIGO clinical practice guideline for acute kidney injury. Kidney Int 2012;2:1-138. [Full Text] [Crossref]

43. Macedo E. Urine Output Assessment as a Clinical Quality Measure. Nephro 2015;131:252-4. [PubMed] [Full Text] [Crossref]

44. Vincent JL, Moreno R. Clinical review: scoring systems in the critically ill. Crit Care 2010;14:207. [PubMed] [Full Text] [Crossref]

45. Knaus WA, Zimmerman JE, Wagner DP, Draper EA, Lawrence DE. APACHE-acute physiology and chronic health evaluation: a physiologically based classification system. Crit Care Med 1981;9:591-7. [PubMed] [Full text]

46. Zimmerman JE, Kramer AA, McNair DS, Malila FM. Acute Physiology and Chronic Health Evaluation (APACHE) IV: hospital mortality assessment for today's critically ill patients. Crit Care Med 2006;34:1297-310. [PubMed] [Full text] [ $\underline{\text { Crossref] }}$

47. Zimmerman JE, Kramer AA, McNair DS, Malila FM, Shaffer VL. Intensive care unit length of stay: Benchmarking based on Acute Physiology and Chronic Health Evaluation (APACHE) IV. Crit Care Med 2006;34:2517-29. [PubMed] [Full text] [Crossref]

48. Brinkman S, Bakhshi-Raiez F, AbuHanna A, de Jonge E, Bosman RJ, Peelen $\mathrm{L}$, et al. External validation of Acute Physiology and Chronic Health Evaluation IV in Dutch intensive care units and comparison with Acute Physiology and Chronic Health Evaluation II and Simplified Acute Physiology Score II. J Crit Care 2011;26:105. e11. [PubMed] [Full text] [Crossref]

49. Liu V, Turk BJ, Ragins Al, Kipnis P, Escobar GJ. An electronic Simplified Acute Physiology Score-based risk adjustment score for critical illness in an integrated healthcare system. Crit Care Med 2013;41:41-8. [PubMed] [Full text] [Crossref]

50. Metnitz B, Schaden E, Moreno R, Le Gall JR, Bauer P, Metnitz PG; ASDI Study Group. Austrian validation and customization of the SAPS $3 \mathrm{Ad}$ mission Score. Intensive Care Med 2009;35:616-22. [PubMed] [Full text] [Crossref]

51. Poole D, Rossi C, Latronico N, Rossi G, Finazzi S, Bertolini G; GiViTI. Comparison between SAPS II and SAPS 3 in predicting hospital mortality in a cohort of 103 Italian ICUs. Is new always better? Intensive Care Med 2012;38:1280-8. [PubMed] [Full text] [Crossref]

52. Rothen HU, Stricker K, Einfalt J, Bauer P, Metnitz PG, Moreno RP, et al. Variability in outcome and resource use in intensive care units. Intensive Care Med 2007;33:1329-36. [PubMed] [Full text] [Crossref]

53. Higgins TL, Teres D, Copes WS, Nathanson BH, Stark M, Kramer AA. Assessing contemporary intensive care unit outcome: an updated Mortality Probability Admission Model (MPMO-
III). Crit Care Med 2007;35:827-35. [PubMed] [Full text] [Crossref]

54. Pettilä V, Pettila M, Sarna S, Voutilainen P, Takkunen 0 . Comparison of multiple organ dysfunction scores in the prediction of hospital mortality in the critically ill. Crit Care Med 2002;30:170511. [PubMed] [Full text]

55. Zygun D, Berthiaume L, Laupland K, Kortbeek J, Doig C. SOFA is superior to MOD score for the determination of non-neurologic organ dysfunction in patients with severe traumatic brain injury: a cohort study. Crit Care 2006;10:R115. [PubMed] [Full text] [Crossref]

56. Sinuff T, Adhikari NK, Cook DJ, Schünemann HJ, Griffith LE, Rocker $\mathrm{G}$, et al. Mortality predictions in the intensive care unit: comparing physicians with scoring systems. Crit Care Med 2006;34:878-85. [PubMed] [ㅍll text] [Crossref]

57. Ferreira FL, Bota DP, Bross A, Mélot $C$, Vincent JL. Serial evaluation of the SOFA score to predict outcome in critically ill patients. JAMA 2001;286:1754-8. [PubMed] [Full text] [Crossref]

58. Cabrè L, Mancebo J, Solsona JF, Saura P, Gich I, Blanch L, et al: Bioethics Working Group of the SEMICYUC. Multicenter study of the multiple organ dysfunction syndrome in intensive care units: the usefulness of Sequential Organ Failure Assessment Score in decision making. Intensive Care Med 2005;31:927-33. [PubMed] [Full text] [Crossref]

59. Halim DA, Murni TW, Redjeki IS. Comparison of Apache II, SOFA, and Modified SOFA Scores in Predicting Mortality of Surgical Patients in Intensive Care Unit at Dr. Hasan Sadikin General Hospital. Crit Care \& Shock 2009;12:157-69. [Full text pdf]

60. Singer M, Deutschman CS, Seymour CW, Shankar-Hari M, Annane D, Bauer M, et al. The Third International Consensus Definitions for Sepsis and Septic Shock (Sepsis-3). JAMA 2016;315:801-10. [PubMed] [Full text] [Crossref]

61. Seymour CW, Liu VX, Iwashyna TJ, Brunkhorst FM, Rea TD, Scherag A, et al. Assessment of Clinical Criteria for Sepsis: For the Third International Consensus Definitions for Sepsis and Septic Shock (Sepsis-3). JAMA 2016;315:762-74. [PubMed] [Full 


\section{text] [Crossref]}

62. Shankar-Hari M, Phillips GS, Levy ML, Seymour CW, Liu VX, Deutschman CS, et al Sepsis Definitions Task Force. Developing a New Definition and Assessing New Clinical Criteria for Septic Shock: For the Third International Consensus Definitions for Sepsis and Septic Shock (Sepsis-3). JAMA 2016;315:775-87. [PubMed] [Full text] [Crossref]

63. Barr J, Fraser GL, Puntillo K, Ely EW, Gélinas C, Dasta JF, et al; American College of Critical Care Medicine. Clinical practice guidelines for the management of pain, agitation, and delirium in adult patients in the intensive care unit. Crit Care Med 2013;41:263306. [PubMed] [Full text] [Crossref]

64. Chanques G, Viel E, Constantin JM, Jung B, de Lattre S, Carr J, et al. The measurement of pain in intensive care unit: Comparison of 5 self report intensity scales. Pain 2010;151:71121. [PubMed] [Full text] [Crossref]

65. Sessler CN, Jo Grap M, Ramsay MA. Evaluating and monitoring analgesia and sedation in the intensive care unit. Crit Care 2008;12Suppl 3:S2. [PubMed] [Full text] [Crossref]

66. Payen JF, Bru 0, Bosson JL, Lagrasta A, Novel E, Deschaux I, et al. Assessing pain in critically ill sedated patients by using a behavioral pain scale. Crit Care Med 2001;29:225863. [PubMed] [Full text]

67. Gélinas C. Nurses' evaluation of the feasibility and clinical utility of the Critical-Care Pain Observation Tool. Pain Manag Nurs 2010;11:115-25. [PubMed] [Full text] [Crossref]

68. Severgnini P, Pelosi P, Contino E, Serafinelli $E$, Novario $R$, Chiaranda $M$. Accuracy of Critical Care Pain Observation Tool and Behavioral Pain Scale to assess pain in critically ill conscious and unconscious patients: prospective, observational study. J Intensive Care 2016;4:68. eCollection 2016. [PubMed] [Full text] [Crossref]

69. De Jonghe B, Bastuji-Garin S, Fangio $P$, Lacherade JC, Jabot J, Appéré-De-Vecchi $C$, et al. Sedation algorithm in critically ill patients without acute brain injury. Crit Care Med 2005;33:120-7. [PubMed] [Full text]
[Crossref]

70. Pun BT, Dunn J. The sedation of critically ill adults - part 1: assessment: the first in a two-part series focuses on assessing sedated patients in the ICU. Am J Nurs 2007;107:40-8. [PubMed] [Full text] [Crossref]

71. Salluh JI, Wang $H$, Schneider EB, Nagaraja N, Yenokyan G, Damluji $A$, et al. Outcome of delirium in critically ill patients: Systematic review and meta-analysis. BMJ 2015;350:h2538. [PubMed] [Full text] [Crossref]

72. Luetz A, Weiss B, Boettcher S, Burmeister J, Wernecke KD, Spies C. Routine delirium monitoring is independently associated with a reduction of hospital mortality in critically ill surgical patients: A prospective, observational cohort study. J Crit Care 2016;35:168-73. [PubMed] [Full text] [Crossref]

73. Andrews L, Silva SG, Kaplan S, Zimbro K. Delirium monitoring and patient outcomes in a general intensive care unit. Am J Crit Care 2015;24:48-56. [PubMed] [Full text] [Crossref] 